\title{
Population Dynamics of Pometia for The Period of Post-Selective Logging in Tropical Rainforest, Southern Papua, Indonesia
}

\author{
${ }^{\square}$ Agustinus Murdjoko',4, Djoko Marsono $^{2}$, Ronggo Sadono ${ }^{2}$, Suwarno Hadisusanto ${ }^{3}$ \\ DOI: 10.15294/biosaintifika.v8i3.6309 \\ ${ }^{1}$ Faculty of Forestry, Papua University, Manokwari, West Papua, Indonesia \\ ${ }^{2}$ Faculty of Forestry, Gadjah Mada University, Yogyakarta, Indonesia \\ ${ }^{3}$ Faculty of Biology, Gadjah Mada University, Yogyakarta, Indonesia \\ ${ }^{4}$ Doctoral Program of Forest Science, Gadjah Mada University, Yogyakarta, Indonesia
}

\section{History Article}

Received 16 June 2016 Approved 4 October 2016 Published 24 December 2016

\section{Keywords:}

integral projection model; population growth rate $(\lambda)$; remnant stands; logged forest

\begin{abstract}
Tropical rainforest changed in term of structure, composition and population, resulting from logging. One of target trees during logging is Pometia. Our goals of this research were to answer that (1) How were survival, growth, fecundity and population growth rate $(\lambda)$ of Pometia within remnant stands?; (2) what were driving factors to explain population dynamics of Pometia within logged forest?. Data were derived from three hectares-permanent sample plot (PSP) in logged forest of PT Tunas Timber Lestari. Integral Projection Models (IPMs) were applied to analyze population dynamics. The study showed dynamically that probability of the individuals of Pometia survived in this area did not significantly differ among their size, while stands showed the significant difference between small and large individuals. The growth of both individuals of Pometia and stands varied significantly in different size. The probability of fecundity both Pometia and stands were significantly different among size. The population of Pometia has been increasing for about a decade as the population of all stands was growing as well. Moreover, the regular documentation of species composition and structure before and after logging is necessary as a control of biodiversity. Therefore, a proper protocol to monitor the biodiversity should be designed by government and disseminated it to logging companies.
\end{abstract}

\section{How to Cite}

Murdjoko, A., Marsono, D., Sadono, R. \& Hadisusanto, S. (2016). Population Dynamics of Pometia for The Period of Post-Selective Logging in Tropical Rainforest, Southern Papua, Indonesia. Biosaintifika: Journal of Biology \& Biology Education, 8(3), 321-330.

(C) 2016 Universitas Negeri Semarang 


\section{INTRODUCTION}

Tropical rainforest can be seen as a succession mechanism in which, at a certain point, equilibrium is reached when species composition is stable and highly adapted to a certain environment (Bunyan et al., 2015; Corlett, 2016). The tropical rain forest at the equilibrium stage means that the forest is categorized as primary forest. However, the forest will change in term of composition and structure as result of disturbances, which are mainly due to anthropogenic factors. Then, the forest will recuperate and this dynamic of the forest is referred to the tropical secondary forest (Castro-Luna et al., 2011).

The southern part of Papua is a lowland tropical rainforest and some parts of them have been experiencing logging for about over the past decades (Kuswandi \& Murdjoko, 2015; Kuswandi, 2014; Murdjoko, 2013). Hence, this leads to alterations of floristic composition, structure as well as the growth of vegetation in logged forest as a response to logging impact (de Avila et al., 2015; Sandor \& Chazdon, 2014). Moreover, the structural change of forest is an impact on dynamic processes such as mortality, growth, recruitment as well as fecundity. Consequently, population growth rate of logged forest would also alter, since ecological condition changed ( $\mathrm{Lu}$ et al., 2015). Study of population growth rate can be focused on either total stands regardless species or certain species.

Species of Pometia are present widely in Papua (Kuswandi et al., 2015), but less is still known related to population and its re-growth in the forest. Thus, this study took species of genus of Pometia that are growing in logged forest and those species are the target during selective logging. As a result, the growth of remnant trees of those species altered post-selective logging forest. Dynamic trees of Pometia involve mortality, growth, fecundity and recruitment of these trees over the time as dynamic variables. The dynamics are not similar for each period and influenced by ecological change. The change of dynamic trees results from the change in the variables over the time. Consequently, structure and distribution of Pometia trees will vary as well. The alteration of growth of Pometia trees is actually slow during a short time. Fortunately, new tools of dynamic analysis have been developed, one of which is integral projection model (IPM). This tool can detect population growth rate for long-term growth (Zuidema et al., 2009; Zuidema et al., 2010) as an indicator of how tree dynamic behaves to the alteration of the condition of tropical rainforest.
For that reason, to what extent the Pometia trees influenced by selective logging is, therefore, interesting to be investigated.

Here we designed the goals of this research to answer some questions that (1) How were survival, growth, fecundity and population growth rate $(\lambda)$ of Pometia within remnant stands?; (2) what were driving factors to explain population dynamics of Pometia within logged forest?.

\section{METHODS}

Research was conducted in permanent sample plot (PSP) where this is a selectively logged forest and assumed as representative of post-logging in alluvial-lowland forest. Geographical position is $140^{\circ} 21^{\prime} 00^{\prime \prime}-140^{\circ} 59^{\prime} 00^{\prime \prime}$ $\mathrm{E}$ and $05^{\circ} 50^{\prime} 50^{\prime \prime}-06^{\circ} 42^{\prime} 00^{\prime \prime} \mathrm{S}$. This belongs to concession area of PT Tunas Timber Lestari. This logged tropical rainforest is characterized by annual average rainfall ranging from 3.000 to $4.000 \mathrm{~mm}$, daily moisture between 75 and 85 per cent. Most of the soil is from alluvial processes (Petocz, 1989). Trees in this logged forest were dominated by families of Dipterocarpaceae, Lauraceae and Myrtaceae (Gandhi \& Mitlöhner, 2014). Species of Vatica rassak and Syzygium sp. were mostly dominated as small and large trees in logged forest (Kuswandi et al., 2015).

Species are focused on genus of Pometia where some species have been taxonomically named. Therefore, they only use "sp" for a genus of Pometia. One species has been identified as Pometia pinnata J.R. Forst\& G. Forst and belongs to Sapindaceae (soapberry family). Subfamily is Nepheliae (tribe). This tree grows widely in Asia-Pacific region. Distribution of the species is dominantly in lowland subtropical and tropical area from around $14^{\circ} \mathrm{N}$ to $20^{\circ} \mathrm{S}$. Pometia is native to Borneo (forma acuminate, f. glabra and f. alnifolia, plus other paramorphs), eastern Indonesia (forma cuspidate and f. pinnata), India (probably f. glabra and f. tomentosa), Laos, Papua New Guinea (f. piñata, f. glabra and f. repanda), Malaysia, Papua, South Cina (f. tomentosa), south pacific, southern Thailand, Sri Lanka Taiwan and Vietnam. In Papua, Pometia is called kalasina, kablauw, iwa (Sentani language). Orwa, Mutua, Kindt, Jamnadass, \& Anthony (2009) mentioned 8 forms of Pometia pinnata J.R. Forst\& G. Forst namely forma pinnata (synonym: P. coriacea Radlk. 1913); f. acuminata (Hook.f.) Jacobs's synonyms: P.acuminata (Hook.f.) Radlk. 1877, P.annamica Gagn. (1947); f. alnifolia (Blume) Jacobs (synonym: P. alnifolia (Blume) Radlk. 1877); f. cuspidata (Blume) Jacobs; f. glabra (Blume) Jacobs (synonym: $P$. 
pinnata var. javanica Koord. \& Valeton, 1903); f. macrocarpa (Kurz) Jacobs (synonym: P. macrocarpaKurz, 1875); f. repandra Jacobs; f. tomentosa (Blume) Jacobs (synonym: $P$. tomentosa (Blume) Teijsm. \& Binnend. (1866).Pometia generally grow as dominant tree in which trees are very abundant and canopy emergent over other tree species. Associated plant species of this species mainly take place in evergreen or occasionally deciduous closed forest and secondary forest. Name of species that strongly associate with Pometia can be seen in Thomson \& Thaman (2006). Climatic condition from warm to hot, humid, subtropical and tropical are proper to Pometia. Then, distribution of Pometia is from elevation $0-1700 \mathrm{~m}$ a.s.1. while mean annual rainfall is $1500-5000$ $\mathrm{mm}$. Pometia has a wide edaphic range especially better-drained sites while acidity should be from pH 4.0 - 8.0 (Orwa et al., 2009; Thomson \& Thaman, 2006).

To meet the requirements of population dynamic analysis, periodic data were collected in PSP in which size of PSP is three hectares distributed in selectively logged forest. The data contained measurement in previous time $\left(\mathrm{T}_{0}\right)$ and current time $\left(\mathrm{T}_{1}\right)$ as a period for each tree species or individuals in this area as remnant stands including Pometia. Information from PSP was mortality described as number of trees die in $\mathrm{T}_{1}$ were documented; growth described as difference of diameter at $\mathrm{T}_{1}$ and $\mathrm{T}_{0}$; fecundity defined as number of new individuals enter trees at $\mathrm{T}_{0}$. The minimum diameter was $10 \mathrm{~cm}$. The PSP were established just one year after logging which was in 2015 . Then, data were measured annually between May and July. Therefore, the data comprise 10 year-measurement that consisted of nine periods.

Basal area (BA) of Pometia and stands was computed as $\mathrm{BA}_{i}=\sum \mathrm{D}_{i}^{2} \times 0.7854$, where $\mathrm{BA}_{\mathrm{i}}$ is basal area $\left(\mathrm{m}^{2}\right)$ of tree species $i, D_{i}$ is diameter (m) of tree species $I$ and 0.7854 is $\pi / 4$. Then, the basal area was set in a hectare $\left(\mathrm{m}^{2} \mathrm{ha}^{-1}\right)$. Density was computed as number of individual per hectare (ind. ha ${ }^{-1}$ ). Those variables will be calculated using logistic regression to obtain probability of individual tree dies over time. The survival is that one is subtracted by the probability of mortality. Then, the logistic regression is expressed as follows $[\mathrm{Y} /((1-\mathrm{Y}))]=\mathrm{a}+\mathrm{bDBH}$, where $\mathrm{Y}$ is probability of mortality or recruitment of individual tree, $a$ is intercept, $b$ is coefficient of regression and $\mathrm{DBH}$ is individual in diameter at breast height (m). After getting the equation, then we will calculate the predicted probability of mortality or recruitment of species in each DBH by applying the back transformation. Then, $\mathrm{Y}$ can be determined as $\mathrm{Y}=\mathrm{e}^{\wedge}(\mathrm{a}+\mathrm{bDBH}) /\left(1-\mathrm{e}^{\wedge}(\mathrm{a}+\mathrm{bDBH})\right)$. Number of new individuals that enter tree forest was calculated by making equation between fecundity and parent tree in certain DBH. Then, relationship was expressed mathematically using equation as $\hat{y}=f(P t r)$, where is predicted value of fecundity and Ptr is parent tree. The equations were tested using either linear or nonlinear regression. Significant equation and the highest value of $\mathrm{R}^{2}$ adj were used to determine the best equation of fecundity. Difference of $\mathrm{DBH}(\triangle \mathrm{DBH})$ between $\mathrm{T}_{1}$ and $\mathrm{T}_{0}$ can be used to define growth of individual tree. Then, the growth was estimated by correlating $\triangle \mathrm{DBH}$ with individual as $\triangle \mathrm{DBH}=\mathrm{f}(\mathrm{DBH})$, where $\triangle \mathrm{DBH}$ is growth of individual tree, $D B H$ is individual in diameter at breast height $(\mathrm{m})$ and $f$ is function of relationship. Data of PSP consisted of annual information of recruitment, growth, mortality of Pometia. Data of other trees growing along with Pometia were also taken into account to compare how dynamic of other trees impact on dynamic of Pometia trees. Then, those set in model as state variables and then dynamic model were run using those variables over time. The IPMs are suitable to explain long-term growth of trees (M. Rees \& Ellner, 2009; Mark Rees, Childs, \& Ellner, 2014; Mark Rees \& Ellner, 2016; Zuidema et al., 2010). Then, procedure of IPM was completed by means of an application on publications (Merow et al., 2014; M. Rees \& Ellner, $2009)$. Then, population growth rate $(\lambda)$ was derived from the computation to explain contribution to $\lambda$ of individual based on size distribution (Ellner \& Rees, 2006). If $\lambda>1$ meaning that population is increasing or vice versa (Ma et al., 2016). Data was analyzed by using $\mathrm{R}$ statistical program version 3.1.2. (R Development Core Team, 2005) and we used codes from IPMpack package (Metcalf et al., 2013).

\section{RESULTS AND DISCUSSION}

\section{Population dynamics of Pometia during post- selective logging}

Firstly, we present intercepts and slopes of equations of survival, growth and fecundity of each individual of Pometia (Table 1). Based on the equations of survival, trees that survived after logging mostly did not count on tree size except for the first period. Afterward, the survival function showed a statistical insignificance between tree sizes $(\mathrm{DBH})$ and survived trees in logged forest. Hence, individuals of trees in the forest after logging had an equal probability to survive. In contrast, results of growth equations showed 
significantly relationship between tree size and growth, suggesting that the growth of each individual of tree was not similar among different size of trees (DBH).From the growth functions, the results revealed that the growth of individual tree decreased exponentially with increasing tree size. For a number of new individuals, not all equations were significant between tree size especially large trees assumed as putative parent trees and number of fecundity. The significant equation was only sixth period where intercept and slope have $\mathrm{P}<0.05$. Thus, generally the number of fecundity was not an effect of a number of large trees.

Secondly, most of the equations derived from regression analysis of stands were significant $(\mathrm{P}<0.05)$ for survival function, growth function as well as fecundity function for each period (Table 2). For survival equations, only in fifth period after logging the slope was not significant while for growth and fecundity equations the insignificant slope function were in first and last period after logging; third, seventh and eighth period after logging respectively. Results of those equations suggested that probability of tree mortality varied among tree size (DBH). Similarly, the growth of individuals of stands showed an exponential increase over the time. Moreover, a number of new individuals of stands counted on large trees assumed as putative parent trees, since the equations were significant. The number of new individuals would increase due to the presence of putative parent trees.

Pattern of mortality of stands differed from Pometia in which the stand mortality fluctuated over the period after logging and most of the time below four per cent. Mortality of Pometia from first period to seventh period were zero and in eighth period the mortality of Pometia rose dramatically by about 11 per cent then dropped by zero per cent in last period (Figure 1). There were no significant correlations between mortality of stands and Pometia $(\mathrm{P}>0.05)$.

A number of new individuals of stands differed from Pometia in the first period after logging where fecundity of Pometia accounted for about 30 per cent of a total number of individuals, whereas fecundity of stands was about 5 per cent of total individuals. After the third period of postlogging, the shape of both mortalities fluctuated from zero to about 10 per cent (Figure 2). Neither mortality of stands nor mortality of Pometia influenced each other in logged forest.

Table 1. Coefficients (intercepts and slopes) of survival function, growth function and fecundity function of Pometia. The Significant codes are that ${ }^{*}=\mathrm{P}<0.05$, ${ }^{* *}=\mathrm{P}<0.01$ and ns $=$ not significant or $\mathrm{P}>0.05$.

\begin{tabular}{|c|c|c|c|c|c|c|c|}
\hline \multirow{2}{*}{ period } & \multirow{2}{*}{ Coefficients } & \multicolumn{2}{|c|}{ survival function } & \multicolumn{2}{|c|}{ growth function } & \multicolumn{2}{|c|}{ fecundity function } \\
\hline & & estimate & & estimate & & estimate & \\
\hline \multirow[t]{2}{*}{ t1 } & intercept & $-4.66 \mathrm{E}+00$ & * & 1.045 & ** & 0.063 & ns \\
\hline & slope & 7.48E-02 & * & 0.997 & ** & 0.003 & ns \\
\hline \multirow[t]{2}{*}{ t2 } & intercept & $2.46 \mathrm{E}+01$ & ns & 1.479 & ** & 0.173 & * \\
\hline & slope & $1.92 \mathrm{E}-11$ & ns & 0.980 & ** & -0.002 & ns \\
\hline \multirow[t]{2}{*}{ t3 } & intercept & $2.46 \mathrm{E}+01$ & ns & 1.782 & ** & 0.414 & ns \\
\hline & slope & $1.37 \mathrm{E}-11$ & ns & 0.978 & ** & -0.006 & ns \\
\hline \multirow[t]{2}{*}{14} & intercept & $2.46 \mathrm{E}+01$ & ns & 1.431 & ** & 0.147 & * \\
\hline & slope & $-2.44 \mathrm{E}-08$ & ns & 0.984 & ** & -0.002 & ns \\
\hline \multirow[t]{2}{*}{ t5 } & intercept & $2.46 \mathrm{E}+01$ & ns & 1.330 & ** & 0.166 & ns \\
\hline & slope & $-2.51 \mathrm{E}-11$ & ns & 0.989 & ** & 0.000 & ns \\
\hline \multirow[t]{2}{*}{ t6 } & intercept & $2.46 \mathrm{E}+01$ & ns & 1.045 & ** & -4.571 & * \\
\hline & slope & $3.19 \mathrm{E}-11$ & ns & 0.997 & ** & 0.074 & * \\
\hline \multirow[t]{2}{*}{ t7 } & intercept & $2.56 \mathrm{E}+01$ & ns & 0.704 & ** & 0.063 & ns \\
\hline & slope & $5.36 \mathrm{E}-11$ & ns & 0.999 & ** & 0.003 & ns \\
\hline \multirow[t]{2}{*}{ t8 } & intercept & $1.98 \mathrm{E}+00$ & * & 0.799 & ** & 0.275 & * \\
\hline & slope & $1.98 \mathrm{E}-02$ & ns & 0.996 & ** & -0.005 & ns \\
\hline \multirow[t]{2}{*}{ t9 } & intercept & $2.56 \mathrm{E}+01$ & ns & 0.791 & ** & 0.346 & * \\
\hline & slope & $-1.06 \mathrm{E}-11$ & ns & 0.995 & ** & -0.005 & ns \\
\hline
\end{tabular}




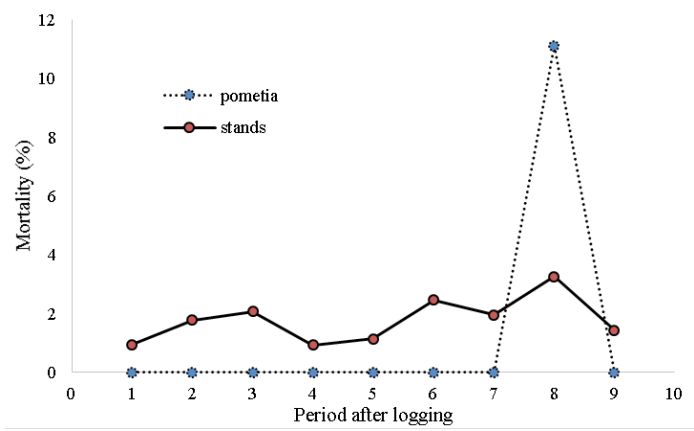

Figure 1. Mortality of Pometia (dashed line) and stands (solid line) over the period of post-logging

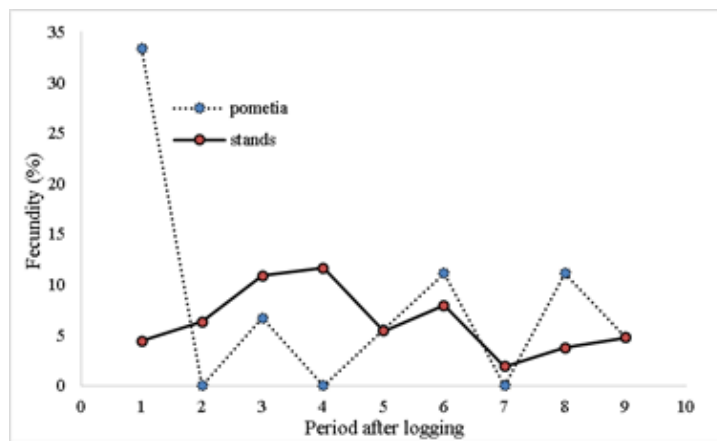

Figure 2. Fecundity of Pometia (dashed line) and stands (solid line) over the period of post-logging.

Growth of both stands and Pometia can be

observed by means of the change of basal area and stem density over the periods of post-logging (Table 3 and 4). Apparently, there are the trend that the basal area of stands and Pometia has been gradually growing for 10 years after logging. However, the stem density of stands declined by about $0.7 \mathrm{~m}^{2} \mathrm{ha}^{-1}$ in 2012 and increased by about three $\mathrm{m}^{2} \mathrm{ha}^{-1}$, while the basal area of stands remained growing.

The relationship between basal area of stands and Pometia showed a significance $(\mathrm{P}<0.05)$ in which both had positive association $\left(\mathrm{R}^{2}=0.98\right)$ where 98 percent variation of basal area of Pometia is explained by basal area of stands. Intercept of regression was not significant $(\mathrm{P}=0.06)$, then eliminated from equation (Figure 4).

Stem density of stands and Pometia showed a positive correlation, since the coefficient of determination $\left(\mathrm{R}^{2}\right)$ is 0.91 in which about 90 per cent variation of stem density of Pometia results from the variation of stand stem density. Besides that, equation of linear regression had a significance $(\mathrm{P}<0.05)$, but the intercept did not show a significance $(\mathrm{P}=0.86)$. Therefore, the equation can be expressed as $\mathrm{y}=0.0072 \mathrm{x}$, where $\mathrm{x}$ is stem density of stands and $\mathrm{y}$ is stem density of Pometia (Figure 3).

Table 2. Coefficients (intercepts and slopes) of survival function, growth function and fecundity function of stands. Significant codes are that $*=\mathrm{P}<0.05, * *=\mathrm{P}<0.01$ and ns $=$ not significant or $\mathrm{P}>0.05$.

\begin{tabular}{|c|c|c|c|c|c|c|c|}
\hline \multirow{3}{*}{$\frac{\text { period }}{\mathrm{t} 1}$} & \multirow{3}{*}{$\frac{\text { Coefficients }}{\text { intercept }}$} & \multirow{2}{*}{\multicolumn{2}{|c|}{$\begin{array}{c}\text { survival function } \\
\text { estimate }\end{array}$}} & \multirow{2}{*}{\multicolumn{2}{|c|}{$\begin{array}{c}\text { growth function } \\
\text { estimate }\end{array}$}} & \multirow{2}{*}{\multicolumn{2}{|c|}{$\frac{\text { fecundity function }}{\text { estimate }}$}} \\
\hline & & & & & & & \\
\hline & & 0.437 & **t & 0.126 & $*$ & -5.313 & *** \\
\hline & slope & 1.001 & ** & -0.001 & ns & 0.069 & ** \\
\hline \multirow[t]{2}{*}{$\mathrm{t} 2$} & intercept & 4.517 & ** & 0.552 & ** & -5.439 & $* *$ \\
\hline & slope & -0.022 & ** & 0.997 & ** & 0.079 & ** \\
\hline \multirow[t]{2}{*}{$\mathrm{t} 3$} & intercept & 4.306 & $* *$ & 0.718 & $* *$ & 0.284 & $* *$ \\
\hline & slope & -0.019 & ** & 1.000 & ** & -0.002 & ns \\
\hline \multirow[t]{2}{*}{$\mathrm{t} 4$} & intercept & 5.007 & $* *$ & 0.673 & ** & 0.343 & ** \\
\hline & slope & -0.016 & $* *$ & 0.996 & ** & -0.005 & ** \\
\hline \multirow[t]{2}{*}{ t5 } & intercept & 4.341 & ** & 0.743 & ** & 0.460 & ** \\
\hline & slope & 0.007 & ns & 0.995 & $* *$ & -0.007 & ** \\
\hline \multirow[t]{2}{*}{ t6 } & intercept & 4.169 & * & 0.738 & ** & 0.498 & ** \\
\hline & slope & -0.022 & ** & 0.999 & ** & -0.007 & $* *$ \\
\hline \multirow[t]{2}{*}{$\mathrm{t} 7$} & intercept & 4.106 & ** & 0.417 & $* *$ & 0.254 & $* *$ \\
\hline & slope & -0.009 & $* *$ & 1.005 & ** & -0.001 & ns \\
\hline \multirow[t]{2}{*}{ t8 } & intercept & 2.857 & $* *$ & 0.562 & ** & 0.349 & ** \\
\hline & slope & 0.028 & $* *$ & 1.000 & ** & -0.003 & ns \\
\hline \multirow[t]{2}{*}{ t9 } & intercept & 0.417 & ** & 0.195 & ** & -5.446 & $* *$ \\
\hline & slope & 1.003 & ** & 0.002 & ns & 0.076 & ** \\
\hline
\end{tabular}


Table 3. Mean and standard deviation $[\bar{x}(\mathrm{SD})]$ of change of basal area $\left(\mathrm{m}^{2} \mathrm{ha}^{-1}\right)$ and stem density (ind. $\mathrm{ha}^{-1}$ ) of stands during period of post-logging

\begin{tabular}{|c|c|c|c|c|c|c|c|c|c|c|}
\hline & \multicolumn{10}{|c|}{ time after logging } \\
\hline & 2005 & 2006 & 2007 & 2008 & 2009 & 2010 & 2011 & 2012 & 2013 & 2014 \\
\hline $\begin{array}{c}\text { basal } \\
\text { area } \\
\left(\mathrm{m}^{2} \mathrm{ha}^{-1}\right)\end{array}$ & $\begin{array}{l}21.17 \\
(5.52)\end{array}$ & $\begin{array}{c}21.91 \\
(5.44)\end{array}$ & $\begin{array}{r}22.41 \\
5.41)\end{array}$ & $\begin{array}{l}23.46 \\
(5.37\end{array}$ & $\begin{array}{r}24.68 \\
5.23)\end{array}$ & $\begin{array}{l}25.79 \\
(5.10)\end{array}$ & $\begin{array}{r}26.64 \\
4.78)\end{array}$ & $\begin{array}{r}27.11 \\
4.43)\end{array}$ & $\begin{array}{l}27.77 \\
(3.94)\end{array}$ & $\begin{array}{l}28.77 \\
(3.59)\end{array}$ \\
\hline $\begin{array}{c}\text { stem } \\
\text { density } \\
\left(\text { ind ha }^{-1}\right)\end{array}$ & $\begin{array}{r}454.00 \\
(54.9)\end{array}$ & $\begin{array}{l}468.67 \\
(44.6)\end{array}$ & $\begin{array}{l}489.00 \\
(33.4)\end{array}$ & $\begin{array}{c}531.67 \\
(31.6)\end{array}$ & $\begin{array}{c}588.00 \\
(24.6)\end{array}$ & $\begin{array}{c}613.00 \\
(23.1)\end{array}$ & $\begin{array}{c}646.33 \\
(22.5)\end{array}$ & $\begin{array}{l}645.67 \\
(17.5)\end{array}$ & $\begin{array}{c}648.67 \\
(18.5)\end{array}$ & $\begin{array}{c}670.00 \\
(25.2)\end{array}$ \\
\hline
\end{tabular}

Table 4. Mean and standard deviation $[\bar{x}(\mathrm{SD})]$ of change of basal area $\left(\mathrm{m}^{2} \mathrm{ha}^{-1}\right)$ and stem density (ind. $\mathrm{ha}^{-1}$ ) of Pometia during period of post-logging

\begin{tabular}{|c|c|c|c|c|c|c|c|c|c|c|}
\hline & \multicolumn{10}{|c|}{ time after logging } \\
\hline & 2005 & 2006 & 2007 & 2008 & 2009 & 2010 & 2011 & 2012 & 2013 & 2014 \\
\hline basal area $\left(m^{2} h a^{-1}\right)$ & $\begin{array}{c}0.33 \\
(0.47)\end{array}$ & $\begin{array}{c}0.34 \\
(0.47)\end{array}$ & $\begin{array}{c}0.35 \\
(0.47)\end{array}$ & $\begin{array}{c}0.37 \\
(0.48)\end{array}$ & $\begin{array}{c}0.38 \\
(0.48)\end{array}$ & $\begin{array}{c}0.39 \\
(0.50)\end{array}$ & $\begin{array}{c}0.41 \\
(0.52)\end{array}$ & $\begin{array}{c}0.43 \\
(0.53)\end{array}$ & $\begin{array}{c}0.42 \\
(0.55)\end{array}$ & $\begin{array}{c}0.44 \\
(0.57)\end{array}$ \\
\hline $\begin{array}{l}\text { stem density } \\
\left(\text { ind. } \mathrm{ha}^{-1} \text { ) }\right.\end{array}$ & $\begin{array}{c}3.00 \\
(1.73)\end{array}$ & $\begin{array}{c}3.67 \\
(1.15)\end{array}$ & $\begin{array}{c}3.67 \\
(1.15)\end{array}$ & $\begin{array}{c}4.00 \\
(1.73)\end{array}$ & $\begin{array}{c}4.00 \\
(1.73)\end{array}$ & $\begin{array}{c}4.33 \\
(2.31)\end{array}$ & $\begin{array}{c}4.67 \\
(2.08)\end{array}$ & $\begin{array}{c}4.67 \\
(2.08)\end{array}$ & $\begin{array}{c}4.67 \\
(2.08)\end{array}$ & $\begin{array}{c}5.00 \\
(2.65)\end{array}$ \\
\hline
\end{tabular}

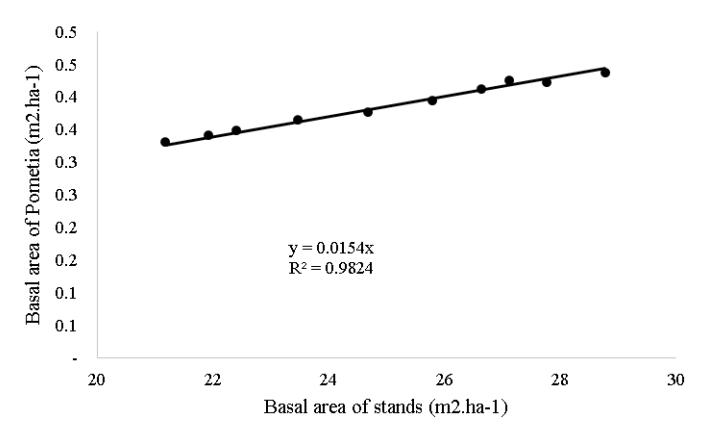

Figure 3. Relationship between basal area of stands (x) and Pometia (y) using linear regression and coefficient of determination $\left(\mathrm{R}^{2}\right)$.

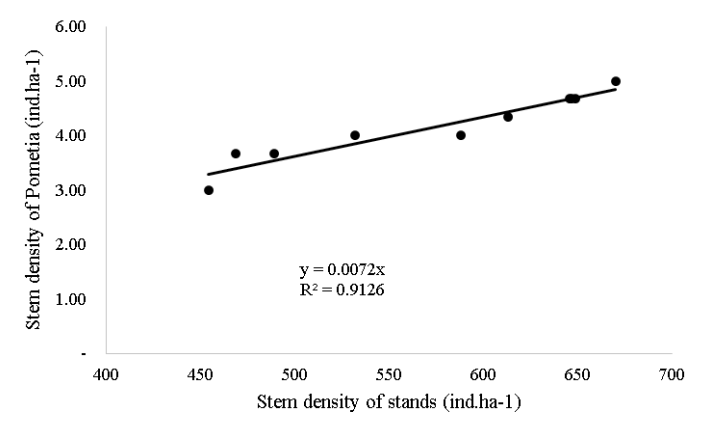

Figure 4. Relationship between stem density of stands (x) and Pometia (y) using linear regression and coefficient of determination $\left(\mathrm{R}^{2}\right)$.

\section{Population growth rate $(\lambda)$ of Pometia within logged forest}

In general, population growth rate $(\lambda)$ of both stands and Pometia have been growing for 10 years after selective logging in which the popula- tion growth rate of them was above one over the time (Figure 5 and 6). We applied power function to fit the population growth rate of stands and Pometia. Moreover, there are trends that population growth rate of stands and Pometia fluctuated during post-selective logging. There was a decline of population growth rate of stands in the beginning of post-selective logging where the population growth rate dropped from about four in the first period to about two in the third period. Afterward, there is a tendency that the increase of population growth rate occurred up to last period and the highest value of population growth rate of stands was reached in the last period (Figure 5).

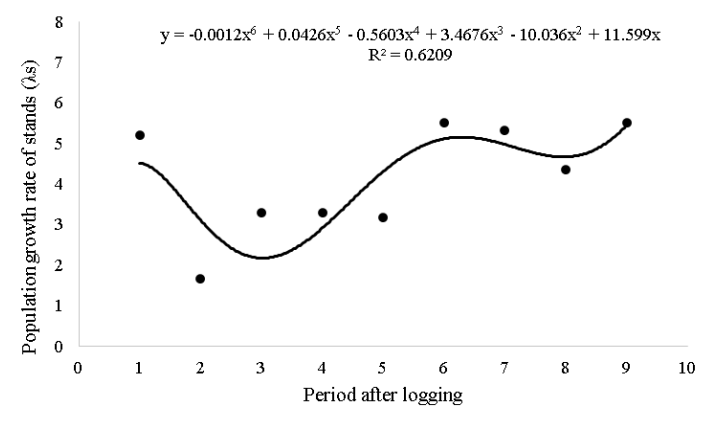

Figure 5. Population growth rate $(\lambda)$ of stands for the period of post-selective logging

In the population growth rate of Pometia, there is a parabolic pattern between the first period and fifth period in which the population growth rate climbed from about one to about six in the second and third period. That was the 
highest value of the population growth rate of Pometia. At a later time, the population growth rate reached the lowest value in the fifth and sixth period where the value was about two, then grew gradually up to last period (Figure 6).

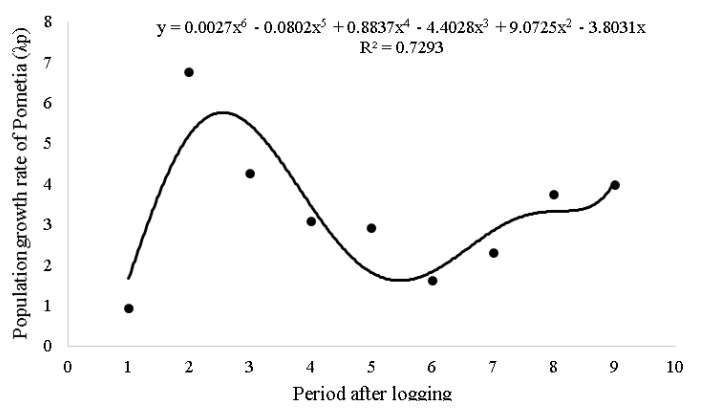

Figure 6. Population growth rate $(\lambda)$ of Pometia for the period of post-selective logging.

\section{Relationship between population growth rate of Pometia and remnant stands}

With respect to the relationship between population growth rate of stands and Pometia, we were able to correlate both of the population growth rates by means of logistic equation. The relationship can be described mathematically as $\mathrm{y}=-3.427 \ln (\mathrm{x})+7.9461$, where $\mathrm{y}$ denotes population growth rate of Pometia and $\mathrm{x}$ is a symbol of population growth rate of stands. The logistic equation was significance $(\mathrm{P}<0.05)$ and the significant correlation can be seen from the coefficient of determination $\left(\mathrm{R}^{2}\right)$, showing that about 63 percent of Pometia population growth rate is associated with stand population growth rate. Both population growth rate showed a tendency in which the population growth rate of Pometia decreased logistically natural with declining population growth rate of stands (Figure 7). However, the population generally increased as the value of both population growth rate were above one.

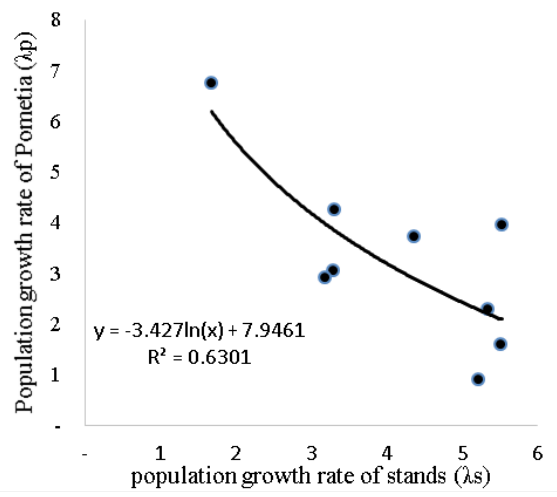

Figure 7. Relationship between population growth rate $(\lambda)$ of stands $(x)$ and Pometia $(y)$ for the period of post-selective logging
Driving factors on alteration of population of Pometia versus remnant stands in selectively logged forest

This study demonstrates that population structures of Pometia were dynamic after logging. It can be seen from the fluctuation of its population growth (Figure 6). The general pattern of the population was growing, since the value of the population of growth rate $(\lambda)$ above one (Lima et al., 2016). Similarly, the population of stands in post-selective logging was rising despite the fact that a gradual decline was in the beginning after logging. Those fluctuations of population growth rate resulted possibly from the gap of the canopy by logging (Fayolle et al., 2014; Kuswandi \& Murdjoko, 2015). This condition can trigger all vegetation to compete each other in order to get sunlight (Win et al., 2012). Since forest was fragmented, the sunlight and space would be more available. Hence, tree species, which are as light-demanding species, would grow rapidly as they get more sunlight and vise versa (Huang et al., 2015).In some conditions, gaps were quite big and the sunlight can reach forest floor (Mesquita et al., 2015). Consequently, trees in particular small individuals require more sunlight after they germinated as early seedling establishment (Adili et al., 2013; Kunstler et al., 2016; Mutiso et al., 2013). Thus, the stands probably grew abundantly triggering fecundity of stands tended to ascend just after logging. Consequently, individuals of Pometia were suppressed in the beginning of post-selective logging period (Figure 3 ). Then, large trees as putative parent trees continued to supply seeds in this logged forest. That is one of the advantages of selective cutting in the tropical forest in which remnant trees can play a crucial role as seed supplier (de Avila et al., 2015; Sandor \& Chazdon, 2014; Seidler \& Plotkin, 2006).

In contrast, the mortality rate of Pometia was relatively zero after the logging except in the eighth period, indicating that residual trees of $\mathrm{PO}$ metia were not affected by logging. Besides that, the probability of survived individuals of Pometia did not differ across size of the individuals (Table 1). Those individuals have shown their ability to outcompete among all individuals. The parabolic pattern of population growth rate of Pometia was presumably because of a number of fecundity. In this logged forest, seeds were produced by large trees, but not all seeds germinate during early seedling establishment stage. Moreover, this stage was very vulnerable to be dying or dead, leading to the decrease of fecundity (Adili et al., 2013). In logged forest, not only trees compete and interact each other, but other vegetation from other life- 
forms also share and compete as symbiotic processes (Murdjoko et al., 2016). Thus, the number of new individuals entering into population varied over the periods of post-selective logging. Furthermore, the growth of residual trees of Pometia significantly contributed (Table 1) to its population growth rate as the residual trees grew rapidly resulting from receiving more sunlight and space. Then, the individuals of Pometia could take advances of gap condition in logged forest. As a consequence, they reached to the large size of individuals in short time. Therefore, this resulted in an increase of population growth rate of Pometia.

Not only residual trees of Pometia, but also the other stands growing along whether as the competitor or as facilitator influenced the growth of Pometia population. In this logged forest, Pometia was not as the most dominant trees (Kuswandi et al., 2015). At the same time, population growth rate of stands also rose, suggesting that in general population of trees after logging has been growing for about a decade (both $\lambda>$ one, Figure 5 and 6 ). This is in line with previous research for other species in this area that after selective logging e.g. Vatica rassak, Syzygium sp., Litsea timoriana and Canarium asperum (Kuswandi \& Murdjoko, 2015) were growing as well. In contrast, previous research showed that some tree species like Actinodaphne nitida and Blumeodendron sp did not show a rapid growth, even though there was an optimistic prediction that those species would recuperate from damage by logging (Murdjoko, 2013).

In this research, we here analyzed the relationship between the growth of Pometia and stands by means of non-linear regression (Figure 7). In the early stage of post-selective logging, both population growth rate of Pometia and stands were higher than in the late stage of postselective logging. Then, their population growth rate in advance would logistically decrease and predictably remain constant with their value equal to about one. This condition would be in the dynamic equilibrium stage of forest (Lima et al., 2016; Ma et al., 2016).

\section{Implications for ecological forest management}

The results of this study contribute to the management of logged forest for Pometia and stands. The logged forest in this area is not the replanted forest. However, remnant trees can play a crucial role as putative parent trees in which they produce new individuals by seeds. During post-selective logging, Pometia, as an example of tree species in this forest, could survive and the population does grow. Hence, sustainability of tree species can be maintained as long as selective logging only harvest based on minimum cutting diameter, then left tree species as seed producers. Therefore, cruising timber before logging is important in order to control what tree species are allowed to be cut. Moreover, there is a recommendation for silvicultural system especially selective logging that species composition and structure pre-and post-logging in forest concession should be taken into consideration.

\section{CONCLUSIONS}

This study showed dynamically an alternation of the population of Pometia in post-selective logging during 10 years. The probability of the individuals of Pometia survived in this area did not significantly differ among their size $(\mathrm{DBH})$, while stands showed the significant difference between small and large individuals. The growth of both individuals of Pometia and stands varied significantly in different size (DBH). The number of new individuals of Pometia and stands was mainly from larger individuals, which was assumed as putative parent trees, since the probability of fecundity of both Pometia and stands were significantly different among size (DBH).

The population of Pometia has been increasing for about a decade as the population of all stands was growing as well, resulting from more gap of the canopy. The presence of larger trees is the crucial role as putative parent trees in which the trees would supply new individuals by providing seeds. Therefore, documentation of species composition and structure before and after logging is necessary as a control of biodiversity.

\section{ACKNOWLEDGMENTS}

This research was funded by Beasiswa Pendidikan Pascasarjana Dalam Negeri (BPPDN) 2014 and Manokwari Regency. We thank Devininda Oktaviani (for proofreading), Relawan Kuswandi, Daud Bano, Dedy Subrata May, Vinoba Chandra, Ari Wibowo, Anton Bongga, Sri Emy Rahayu and all staff in PT Tunas Timber Lestari. We are extremely grateful to anonymous reviewers for useful remarks.

\section{REFERENCES}

Adili, B., E1 Aouni, M., \& Balandier, P. (2013). Unravelling The Influence Of Light, Litter And Understorey Vegetation On PinusPinea Natural Regeneration. Forestry, 86(3), 297-304.

Bunyan, M., Bardhan, S., Singh, A., \& Jose, S. (2015). Effect of Topography on The Distribution Of 
Tropical Montane Forest Fragments : A Predictive Modelling Approach. Journal of Tropical Forest Science, 27(1), 30-38.

Castro-Luna, A., Castillo-Campos, G., \& Sosa, V. (2011). Effects Of Selective Logging And Shifting Cultivation On The Structure And Diversity Of A Tropical Evergreen Forest In South-Eastern Mexico. Journal of Tropical Forest Science, 23(1), 17-34.

Corlett, R. T. (2016). The Impacts of Droughts in Tropical Forests. Trends in Plant Science, Xx, (In Press). De Avila, A. L., Ruschel, A. R., De Carvalho, J. O. P., Mazzei, L., Silva, J. N. M., Lopes, J. Do C., ...Bauhus, J. (2015). MediumTerm Dynamics of Tree Species Composition in Response to Silvicultural Intervention Intensities in A Tropical Rain Forest. Biological Conservation, 191, 577-586.

Ellner, S. P., \& Rees, M. (2006). Integral Projection Models for Species with Complex Demography. The American Naturalist, 167(3), 410-428.

Fayolle, A., Picard, N., Doucet, J., Swaine, M., \&Bayol, N. (2014). Forest Ecology And Management A New Insight In The Structure, Composition And Functioning Of Central African Moist Forests. Forest Ecology and Management, 329, 195-205.

Gandhi, Y., \&Mitlöhner, R. (2014). Tree Species Composition, Diversity and Structure in Tunas Logging Concession Area of Papua-Indonesia. Tree, 66, 47.

Huang, Y., Ai, X., Yao, L., Zang, R., Ding, Y., Huang, J., ... Liu, J. (2015). Changes In The Diversity Of Evergreen And Deciduous Species During Natural Recovery Following Clear-Cutting In A Subtropical Evergreen-Deciduous Broadleaved Mixed Forest Of Central China. Tropical Conservation Science, 8(4), 1033-1052.

Kunstler, G., Falster, D., Coomes, D., Hui, F., Kooyman, R., Laughlin, D., ...Aiba, M. (2016). Plant Functional Traits Have Globally Consistent Effects On Competition. Nature, 529(7585), 204-207.

Kuswandi, R. (2014). The Effect of Silvicultural Treatment on Stand Growth of Logged-Over Forest in South Papua. Indonesian Journal of Forestry Research, 1(2), 117-126.

Kuswandi, R., \& Murdjoko, A. (2015). Population Structures of Four Tree Species in Logged-Over Tropical Forest in South Papua, Indonesia : An Integral Projection Model Approach. Indonesian Journal of Forestry Research, 2(2), 93-101.

Kuswandi, R., Sadono, R., Supriyatno, N., \& Marsono, D. (2015). Keanekaragaman Struktur Tegakan Hutan Alam BekasTebangan BerdasarkanBiogeografi di Papua. Jurnal Manusia dan Lingkungan, 22(2), 151-159.

Lima, R. A. F., Muller-Landau, H. C., Prado, P. I., \& Condit, R. (2016). How Do Size Distributions Relate To Concurrently Measured Demographic Rates? Evidence From Over 150 Tree Species in Panama. Journal of Tropical Ecology,
32(03), 179-192.

Lu, X., Zang, R., \& Huang, J. (2015). Relationships between community level functional traits of trees and seedlings during secondary succession in a tropical lowland rainforest. PloS one, 10(7), e0132849.

Ma, L., Lian, J., Lin, G., Cao, H., Huang, Z., \& Guan, D. (2016). Forest Dynamics and Its Driving Forces of Sub-Tropical Forest in South China. Scientific reports, 6, 1-10.

Merow, C., Dahlgren, J. P., Metcalf, C. J. E., Childs, D. Z., Margaret, E. K., Jongejans, E., ... Mcmahon, S. M. (2014). Advancing Population Ecology with Integral Projection Models : A Practical Guide. Methods in Ecology and Evolution, 5(2), 99-110.

Mesquita, R. De C. G., Santos, M. P. E. Dos, Massoca, C. C. J., Bentos, T. V., \& Williamson, G. B. (2015). Amazon Rain Forest Succession: Stochasticity or Land-Use Legacy? Bioscience, 65(9), 849-861.

Metcalf, C. J. E., Mcmahon, S. M., Salguero-Gómez, R., \&Jongejans, E. (2013). Ipmpack: An R Package for Integral Projection Models. Methods in Ecology and Evolution, 4(2), 195-200.

Murdjoko, A. (2013). Recuperation of Non-Commercial Trees In Logged Forest in Southern Papua, Indonesia. Jurnal Manajemen Hutan Tropika, 19(2), 94-102.

Murdjoko, A., Marsono, D., Sadono, R., \&Hadisusanto, S. (2016). Plant Species Composition and Their Conspecific Association in Natural Tropical Rainforest, South Papua. Biosaintifika: Journal of Biology \& Biology Education, 8(1), 33-46.

Mutiso, F. M., Hitimana, J., Kiyiapi, J. L., Sang, F. K., \& Eboh, E. (2013). Recovery of Kakamega Tropical Rainforest from Anthropogenic Disturbances. Journal of Tropical Forest Science, 25(4), 566-576.

Orwa, C., Mutua, Kindt R., Jamnadass R., \& Anthony. (2009). Agroforestree Database: a tree reference and selection guide version 4.0. Available: http://www.worldagroforestry.org/sites/ treedbs/treedatabases.asp).

Petocz, R. G. (1989). Conservation and development in Irian Jaya: a strategy for rational resource utilization. Netherlands: Brill.

R Development Core Team. (2005). R: a language and environment for statistical computing, $\mathrm{R}$ Foundation for Statistical Computing, Vienna. Available: http://www.R-project.org.

Rees, M., \& Ellner, S. P. (2009). Integral Projection Models for Populations in Temporally Varying Environments. Ecological Monographs, 79(4), 575-594.

Rees, M., \& Ellner, S. P. (2016). Evolving Integral Projection Models: Evolutionary Demography Meets Eco-Evolutionary Dynamics. Methods in Ecology and Evolution, 7(2), 157-170.

Rees, M., Childs, D. Z., \& Ellner, S. P. (2014). Building Integral Projection Models : A User's Guide. Journal of Animal Ecology, 83(3), 528-545. 
Agustinus Murdjoko, et al. / Biosaintifika 8 (3) (2016) 321-330

Sandor, M. E., \& Chazdon, R. L. (2014). Remnant Trees Affect Species Composition But Not Structure Of Tropical Second-Growth Forest. Plos One, 9(1), e83284.

Seidler, T. G., \& Plotkin, J. B. (2006). Seed Dispersal and Spatial Pattern in Tropical Trees. Plos Biology, 4(11), 2132-2137.

Thomson, L. A. J. \& Thaman, R. R. (2006). Pometiapinnata (tava), ver 2.1, In: Elevitch, C.R. (ed).

Win, R., Suzuki, R., \& Takeda, S. (2012). Effects of Selective Logging on The Regeneration Of Two Commercial Tree Species In The Kabaung Reserved Forest, Bago Mountains, Myanmar.
Journal of Tropical Forest Science, 24(3), 312-321. Zuidema, P. A., Brienen, R. J., During, H. J., \& Güneralp, B. (2009). Do Persistently Fast-Growing Juveniles Contribute Disproportionately To Population Growth? A New Analysis Tool for Matrix Models and Its Application to Rainforest Trees. The American Naturalist, 174(5), 709-719.

Zuidema, P. A., Jongejans, E., Chien, P. D., \& During, H. J. (2010). Integral Projection Models for Trees: A New Parameterization Method and A Validation Of Model Output. Journal of Ecology, 98(2), 345-355. 